\title{
Transition to democracy or hybrid regime? The dynamics and outcomes of democratization in Myanmar
}

\section{Kristian Stokke}

Department of Sociology and Human Geography, University of Oslo

E-mail: kristian.stokke@sosgeo.uio.no

Soe Myint Aung

Department of Political Science, University of Oslo

E-mail: soema@student.sv.uio.no

\begin{abstract}
This article analyses Myanmar's transition from authoritarianism and asks if it represents a transition towards democracy or a hybrid form of rule. Starting from theoretical debates about modes of transition, the article examines competing discourses on Myanmar's opening and argues that it resembles an imposed more than a negotiated transition. Next, the article analyses the links between this mode of transition and its outcomes, and finds that contemporary Myanmar is characterized by a combination of formal institutions for democratic representation, civilian government and power-sharing, and problems of weak popular representation, limited civilian control of the military, and continued centralization of state authority. The article concludes that Myanmar's political trajectory remains open-ended, but also that Myanmar, at least for the time being, seems more accurately described as a relatively stable hybrid regime than as a country that is in transition to democracy.
\end{abstract}

Keywords: mode of transition, authoritarianism, democracy, democratization, hybrid regime, civil-military relations, representation, Myanmar 


\section{Introduction}

Following five decades of military dictatorship (1958-1960, 1962-2011), Myanmar underwent a transition from authoritarianism after the election in 2010 when power was transferred to a nominally civilian government in 2011. The transition was, however, only partial as the new government of President Thein Sein and the Union Solidarity and Development Party (USDP) originated from the military (tatmadaw), came into power through a flawed election and governed on the basis of the militarydesigned 2008 Constitution that granted extensive powers to the tatmadaw. The new government nevertheless initiated key political changes that came to be seen as a democratic opening, including reforms in support of civil and political freedoms, electoral democracy and parliamentary politics at both Union and State/Region levels, and associated initiatives in support of peace and economic liberalization (Cheesman, Farrelly, \& Wilson, 2014; Cheesman, Skidmore, \& Wilson, 2010, 2012; Egreteau, 2016; Gravers \& Ytzen, 2014; Lall, 2016; Steinberg, 2015).

Whereas these political reforms created cautious optimism about the prospects for democratization, peace and development, there were also critical concerns about the substance of Myanmar's democratic opening. Such concerns were strengthened as it became clear that the government was only implementing the military's new Constitution, while refusing to consider constitutional changes that could enable more substantive democracy and peace (Bünte, 2014; Croissant \& Kamerling, 2013). Moreover, the reform process seemed to have stalled by mid-2013 (Mullen, 2016). This meant that although important steps were taken towards basic freedoms, formal democracy and cessation of armed hostilities, the democratic opening stopped far short of achieving liberal democracy and democratic peace.

The political reforms during the USDP government provided a basis for multi-party general elections in 2015, the first since 1990 (Ardeth Maung Thawnghmung, 2016). Electoral observers concluded that the election was free but not completely fair due to weaknesses in the electoral system and the disenfranchisement of large constituencies, especially the Rohingya community. The election returned a landslide victory for the oppositional National League for Democracy (NLD), an equally big defeat for USDP and a relative marginalization of most ethnic parties (Stokke, Khine Win, \& Soe Myint Aung, 2015).

Importantly, the election was followed by peaceful transfer of power to a democratic government, in sharp contrast to the military's annulment of similar election results in 1990 (Huang, 2016). The NLD was allowed to form the first democratic government in five decades, led by Aung San Suu Kyi in a new position as State Counsellor. The 2015 election and the 2016 change of government thus brought major victories for the 
pro-democracy political forces, and raised hopes that procedural democracy could be the basis for further democratization, even though the military continued to hold strong positions of power in Parliament, government and the public administration.

The period since 2016 has, however, challenged such optimistic interpretations and have brought new attention to entrenched institutional, constitutional and political obstacles to substantial democratization. These limitations have especially been demonstrated by the way the military has used its positions of power to prevent the NLD-government from amending the constitution and from achieving substantive peace through political negotiations with ethnic armed organizations (EAOs). The military's continued autonomy and authority is most starkly demonstrated by the offensives against EAOs in Shan, Kachin and Rakhine states and the ethnic cleansing of Rohingyas in Rakhine State (Sadan, 2016; Ware \& Laoutides, 2018). Increased visibility and attention to the continued political power of the military has thus shifted the discourse on democracy in Myanmar, from cautious optimism to critical reexamination of the character and substance of the democratic opening.

The most basic question regarding Myanmar's transition is about how to understand the drivers, character and outcomes of the democratic opening. Is Myanmar a case of the elite-negotiated transitions that are associated with the third wave of democracy, or is it a military-imposed transition? And what are the consequences of Myanmar's mode of transition in terms of democratic substance in the present period and the future? Is Myanmar in a protracted transition to democracy or is it a relatively stable hybrid regime that is likely to dominate politics and government also in the coming years?

The purpose of this review article is to provide an analysis of these questions regarding the mode and outcomes of Myanmar's transition. It pays less attention to the parallel process of negotiating a transition from intrastate conflicts to peace. We recognize that Myanmar's protracted military rule and recent democratic opening are inextricably interwoven with the country's multiple and protracted intrastate conflicts (Callahan, 2003; Smith, 1991, 2018), but the scope of this article is limited to the dynamics and outcomes of democratization. Drawing on theoretical debates about modes of transition and empirical knowledge derived from document sources and qualitative interviews, the article examines the most prominent interpretations and debates regarding the political actors, strategies and dynamics. We argue that Myanmar's political opening should be understood as an imposed transition, revolving around the aim of securing and legitimizing state and military power. The article also observes that the military-led reform process has followed a sequential logic that follows from the military's imperatives, where state security and stability are prerequisites for economic liberalization, formal electoral democracy and peace 
negotiations (Callahan, 2003; Selth, 2001). This approach to democratization has been enabled by the military's position of strength and changing international relations that have provided political space and leverage for the military to pursue its agenda of disciplined or guided democracy.

Next, the article reviews the links between this mode of transition and its outcomes. It argues that Myanmar's mode of transition has institutionalized a hybrid (semiauthoritarian) form of rule where there are new and important democratic spaces, but where the substance of democracy is curtailed by constitutional regulations that guarantee the military positions of power and prevent substantive popular control of public affairs. Contemporary Myanmar is thus characterized by a combination of formal institutions for democratic representation, civilian government and powersharing, on the one hand, and problems of weak political representation, limited civilian control of the military, and continued centralization of state authority, on the other.

In this situation, the article concludes that Myanmar's political trajectory is to some extent open-ended, as demonstrated by the 2015 election and the subsequent change of government. This can be taken as evidence that Myanmar is in a slow and gradual process of further democratization by democratic means, what has been described as a protracted transition (Bünte, 2016; Eisenstadt, 2000). However, the institutionalized power and prerogatives of the military mean that the prospects for such transformative democratic politics remain limited. For the time being, the article concludes that Myanmar can be more accurately described as a relatively stable hybrid regime than as a country that is in transition to democracy.

\section{Modes and outcomes of democratic transitions}

At the most general level, democratization theories have been characterized by an oscillation between structural approaches emphasizing modernization, economic growth, class structures and struggles, and agency approaches focusing on political actors and their strategies in institutionalizing new political rules (Grugel \& Bishop, 2014; Mahoney \& Snyder, 1999). While structural theories dominated earlier studies, democratization studies since the third wave of democracy have given primary attention to the strategies and capacities of political elites (Linz \& Stepan, 1996; O'Donnell \& Schmitter, 1986; Schmitter, 2017). This transition approach has also been the foremost interpretive frame for studies and debates on Myanmar's democratic opening. Questions of economic structures are given less attention, although there are some notable studies of how economic liberalization since the early 1990s has given rise to military companies and a class of cronies and oligarchs with vested 
interests in Myanmar's mode of governance (Ford, Gillan, \& Thein, 2015; Jones, 2013).

It follows from this emphasis on political actors and strategies that transitions may take different forms and produce diverse outcomes. Schmitter (2017), for example, identifies four ideal type modes of transition based on a twofold distinction between elites or masses as the main drivers of transition, and compromise or force as the prevalent strategic orientation of the key actors. While old democracies originated in collective struggles of excluded groups and produced democracy by way of reformist compromises or popular revolutions, the transition approach holds that recent transitions have come from above and either been imposed by incumbent elites or are pacted compromises between previously opposed political elites.

The transition approach argues that third wave transitions reflect the interests and strategies of political elites (Linz \& Stepan, 1996). While the pacted mode of transition has come to be seen as the archetype of the third wave of democracy, transitologists acknowledge that there are notable examples of imposed transitions (Munck \& Leff, 1997; Schmitter \& Karl, 1991; Stradiotto \& Guo, 2010). The critical distinction between pacted and imposed transitions is whether softline autocrats and moderate democrats negotiate a pact - a formal or informal agreement - and thereby seek to reduce the uncertainty of a regime transition and its outcome (Schmitter, 2017). Imposed transitions, in contrast, are designed and implemented unilaterally by ruling autocratic elites with little or no negotiations with oppositional elites. This distinction is central to debates on the democratic opening in Myanmar (Kipgen, 2016).

\section{Myanmar's mode of transition}

Myanmar's transition from authoritarian rule has generated scholarly and political debates about its causes, characteristics and outcome (Cheesman et al., 2014; Egreteau, 2016; Lall, 2016; Mullen, 2016). The democratic opening took many observers by surprise. In fact, the most prevalent theme in scholarly updates on Myanmar in the 2000s was about the resilience and stability of military rule, despite international sanctions and domestic resistance (see for example Ardeth Maung Thawnghmung \& Maung Aung Myoe, 2007, 2008; James, 2006; Kyaw Yin Hlaing, 2004; Tin Maung Maung Than, 2001). While there was critical attention to the prospects for democratization, few observers predicted the democratic opening that followed after the 2008 Constitution, the 2010 parliamentary elections and the 2011 change of government.

Myanmar's transition from military rule challenges structure-oriented perspectives on 
democratization (Kipgen, 2016). Economic modernization theories do not provide convincing explanations in the absence of socio-economic preconditions that would have made Myanmar conducive for democratization. During the authoritarian period, the economy was controlled by the military and their cronies, the state was predatory rather than developmental, and growth was sluggish and unequal. While the military rulers initiated economic liberalization in the 1990s, this supported cronyism and authoritarian rule rather than economic and political liberalism (Jones, 2013; Turnell, 2012). Although there was a partial shift towards oligarchy, the emerging tycoons did not constitute a significant force with strong interest or influence in democratization (Ford et al., 2015).

The transition cannot be convincingly explained by class struggles or civil society mobilization either. The earlier legacy of class struggles had disintegrated, as most vividly demonstrated by the collapse of the Communist Party of Burma (CPB) in 1989, and class forces played a marginal role in pro-democracy mobilizations (Smith, 1991). The military regime was at times confronted by everyday resistance and civil society mobilizations, including pro-democracy movements, student protests, Buddhist Sangha mobilizations and ethnic organizations (Mullen, 2016), but none of these posed serious threats to the survival of the military regime in the 2000s. The leaders of the pro-democracy movements were incarcerated for long time periods and both political and armed organizations were weakened and divided. Everyday resistance was also insufficient to move the military rulers into democratic reforms, leading some domestic and international reform promoters to search for alternative ways of supporting democracy and peace in Myanmar (Holliday, 2011; Mullen, 2016).

Finally, the democratic opening cannot be explained with reference to international pressure either. While Western states imposed comprehensive political and economic sanctions on the military regime since the 1990s, it is difficult to establish a causal relationship between these sanctions and the character and timing of the democratic opening (Chow \& Easley, 2016; Kyaw Yin Hlaing, 2014a). On the contrary, the 2000s were marked by growing frustration with the ineffectiveness of international sanctions. Myanmar's transition from authoritarianism is thus a case that cannot be easily explained with reference to structural changes and preconditions or domestic and external pressures.

In this situation, the debate on Myanmar's opening has largely focused on political actors, their interests and strategies (Cheesman et al., 2014). The debate has especially revolved around two main interpretations: a discourse that sees Myanmar as a context-specific pacted transition and a discourse that portrays the democratic opening as a military-imposed transition. In terms of timeframe, the former discourse pays primary attention to the USDP-government period (2011-2015) while the latter 
discourse emphasises the last decade of the military regime (the 2000s).

\section{A pacted transition?}

The USDP government period was dominated by what could be called a pacted transition discourse. Observers who sought to understand what was seen as a surprising democratic opening gradually came to represent it as a context-specific version of the transition approach to democratization (Cheesman et al., 2014). The main driving force was said to be reformist actors within the military, ascending to government power in 2011 (Pedersen, 2014; Win Min, 2010). This discourse thus rests on an assumed divide within the authoritarian regime, between softliners led by President Thein Sein and hardline autocrats centred on the former Commander-inChief, Senior General Than Shwe. The reformism of the USDP government was depicted as a fragile democratic opportunity that justified a shift to constructive engagement by civil society organizations and international actors, which had earlier relied on confrontational strategies vis-á-vis the military regime (Lall, 2016; Mullen, 2016; Pedersen, 2012).

The transition discourse thus portrays Myanmar's opening as driven by the reformist USDP-government under President Thein Sein (Figure 1). It was assisted by a group of engagement-oriented diaspora and domestic civil society actors, the so-called 'third force' that especially included Myanmar Egress, Vahu Development Institute and Euro-Burma Office (Kyaw Yin Hlaing, 2014b; Lall, 2016; Mullen, 2016). This reform alliance was sought expanded through dialog and transformation of political parties and ethnic armed organizations, shifting them from hardline resistance to pragmatic engagement with the government. It also mobilized diplomatic support and economic aid from international actors, who were searching for alternatives to ineffective sanctions while being cognisant of the economic and geopolitical opportunities arising in Myanmar (Camroux \& Egreteau, 2010; Egreteau, 2016; Kyaw Yin Hlaing, 2014a).

Starting with the pro-democracy opposition the transition discourse highlights that President Thein Sein met Aung San Suu Kyi - the iconic champion of democracy and the leader of the NLD - and amended the electoral law to allow her to stand for future elections (Bünte, 2016, 2017; Egreteau, 2016). The USDP-government also changed the party registration law to enable NLD to re-register as a political party. This produced a 'pact' in the sense that Aung San Suu Kyi and NLD accepted the electoral framework and chose to participate in the 2012 by-election, thereby reversing their earlier decision to boycott the 2010 election under the 2008 Constitution. NLD's change of strategy was followed by ethnic parties within the United Nationalities Alliance (UNA), who had participated in the 1990 election but boycotted the 2010 election (Egreteau, 2016). The alliance of NLD and UNA parties thus converged with a group of electoralist parties that had been created, either by 
the military or through breakaway factions from NLD and UNA parties, for the purpose of contesting the 2010 election. The transition discourse portrays this as a shift from hardline resistance to political engagement within the framework for electoral democracy offered by the USDP government and the 2008 Constitution.

Likewise, the transition discourse also emphasizes the attempts by the USDPgovernment to negotiate peace with ethnic armed organizations. President Thein Sein made unprecedented references to reconciliation in political speeches, invited EAOs to ceasefire negotiations in 2011, and formed a Union Peace Work Committee (UPWC) with government minister Aung Min as chair and chief negotiator (Egreteau, 2016). This was followed by the establishment of a Myanmar Peace Center (MPC) funded by the European Union to support the peace process. An aid-funded Myanmar Peace Support Initiative (MPSI) was also created to provide humanitarian and development assistance in ceasefire areas. Various interim arrangements were established in ceasefire areas to provide public services and build trust between the government and EAOs (South et al., 2018).

The USDP-government's peace initiatives produced more than a dozen bilateral ceasefire agreements in 2011 and 2012, which was seen as a basis for transformation of EAOs into political parties and integration into parliamentary politics. This approach was, however, rejected by EAOs who demanded extra-parliamentary peace negotiations outside the constraints of the 2008 Constitution. In 2015, eight EAOs signed a Nationwide Ceasefire Agreement (NCA), but this did not include the major armed organizations, except Karen National Union (KNU) and Restoration Council of Shan State (RCSS). The list of major non-signatory armed groups included Kachin Independence Organization (KIO), Myanmar National Democratic Alliance Army (MNDAA), Ta'ang National Liberation Army (TNLA), National Democratic Alliance Army (NDAA), United Wa State Army (UWSA) and Arakan Army (AA) (Burma News International, 2017).

These dialog initiatives and changing positions are taken as evidence that Myanmar's democratic opening should be understood as a pacted transition, even if it did not yield formal agreements or institutionalized reform alliances. The USDP-government succeeded in incorporating some pragmatic pro-democracy and pro-federalism actors into parliamentary politics and ceasefire agreements, but failed in regard to others. This created a split between actors that were portrayed as engagement-oriented softliners and engagement-averse hardliners (Pedersen, 2014; Stokke, Vakulchuk, \& $\varnothing$ verland, 2017). Political parties were divided between new electoralist parties and old movement parties over the question of participation in elections and parliamentary politics under the 2008 Constitution (Stokke et al., 2015). Likewise, bilateral and nationwide ceasefire negotiations and agreements produced shifting 
divisions and alliances among EAOs, between signatory and non-signatory groups, which later became the basis for inclusion or exclusion in the NLD-government's Union Peace Conference - 21st Century Panglong (Burke, Williams, Barron, Jolliffe, \& Carr, 2017).

The discourse on pacted transition thus revolves around distinctions between hardliners and softliners within the authoritarian regime and in the prodemocracy/pro-federalism opposition. Emphasis is placed on their willingness or unwillingness to engage pragmatically despite the long history of antagonistic relations. The discourse highlights promising conciliatory initiatives by the USDPgovernment to initiate negotiations and pacts with opposition parties and EAOs, while failures have commonly been ascribed to non-transformation of hardline actors and positions. Less attention is paid to power structures and the extent to which the negotiations and pacts forged structural transformations. Such concerns are, in contrast, central to the imposed transition discourse.

\section{An imposed transition?}

The pacted transition discourse held a dominant position during the USDP government period. There is, however, also an alternative discourse, which is rooted in the long legacy of critical attention to the military and portrays the democratic opening as a military-imposed transition. These two discourses have framed scholarly and political engagements since 2011, producing polarized polemics and engagement strategies in regards to Myanmar's changing political landscape (Mullen, 2016).

The imposed transition discourse argues that Myanmar has seen a top-down reform process whereby the military seeks to fortify state security and political stability; withdraw from direct rule but maintain its economic and political power; and, strengthen the regime's international leverage and legitimacy (Bünte, 2014; Egreteau, 2016; Huang, 2013; Jones, 2014). In contradistinction to the pacted transition discourse, it holds that the military is a relatively coherent force that has shown few signs of major internal divisions between hardliners and softliners. The key to understanding the democratic opening is rather to be found in the interests and strategies of the military, and how they have been shaped and institutionalized in the course of Myanmar's postcolonial history of armed conflicts and authoritarian rule.

In Myanmar, the tatmadaw has controlled the state, directly or indirectly, during most of the postcolonial period (Callahan, 2003; Egreteau, 2016; Nakanishi, 2013; Selth, 2001). This authoritarian legacy goes back to how the Burma Army led the struggle for independence and became the basis for political parties, especially the dominant Anti-Fascist People's Freedom League (AFPFL). Escalating political instability in the early post-colonial period - rooted in antagonisms within the ruling AFPFL; between 
AFPFL and different factions of the Communist Party of Burma (CPB); and, between AFPFL-governments and ethnic insurgencies - created a pretext for a military caretaker government in 1958-1960 and a military coup d'état in 1962 (Callahan, 2003; Smith, 1991). Myanmar thus came under military rule from 1962 to 2011, only interrupted by an internal reorganization in 1988 when the Burma Socialist Programme Party (BSPP) was replaced by the State Law and Order Restoration Council (SLORC), later renamed as State Peace and Development Council (SPDC). Protracted military rule is thus a key to understanding the characteristics and challenges of state and nation building; political regimes and legitimacy; intrastate conflicts and economic development in Myanmar.

Given this political centrality of the military, a key question regards the interests and strategies of the military. One answer is found in the military's own emphasis on the threats posed by divisive domestic politics and foreign interventions. The tatmadaw sees itself as a patriotic army that protects the national causes of non-disintegration of the Union, non-disintegration of national solidarity and perpetuation of sovereignty (Callahan, 2003; Maung Aung Myoe, 2009, 2014; Selth, 2001). The imposed transition discourse holds that the military rulers have seen disciplined democracy as a means of strengthening national security in regards to both domestic and external security threats. It is also argued that the military has been motivated by a need to reduce Myanmar's dependence on China, and has sought to diversify foreign relations through rapprochement with the United States and the European Union in the context of US-China strategic competition in the Indo-Pacific region (Chow \& Easley, 2016; Egreteau \& Jagan, 2013; Lintner, 2014; Maung Aung Myoe, 2015).

In addition to this primacy of sovereignty and security, the imposed transition discourse also points to the military's economic interests. After the 1988 regime reorganization, the military gained totalitarian control of the state, and expanded its fighting capacity, but also became the foremost economic force through militaryowned and crony companies and created a range of welfare, health, and educational privileges for military personnel and their families (Jones, 2014; Selth, 2001; Steinberg, 2013). With the rise of the praetorian state, the tatmadaw became a political and economic elite with vested interests in the continuation of its power (Egreteau, 2016; Selth, 2018). The imposed transition discourse argues that the military-designed opening not only safeguarded such economic interests, but also expanded the opportunities for military-owned and military-affiliated corporations through economic liberalization and foreign investments.

The imposed transition discourse thus sees the character of the democratic opening as being shaped by the tatmadaw's commitment to state security and stability in combination with their economic and political self-interests. It is also observed that these interests have created a sequential logic, where strengthening state authority has been a prerequisite for partial military withdrawal from government, and where the extent of political liberalization is adjusted to the imperatives of security and 
stability. The tatmadaw has focused on building a strong unitary state with territorial sovereignty and a centralized public administration, as a precursor for a circumspect kind of political liberalization where the military functions as a caretaker of transition and a guardian of the state (Bünte, 2014; Egreteau, 2016).

The two discourses also differ in terms of their historical focus. Whereas the pacted transition discourse emphasizes the period after the change of government in 2011, the imposed transition discourse sees the reforms during the USDP-government as the culmination of a much longer process. The roots of the present opening are especially traced to two critical junctures, the military's National Convention and ceasefire agreements in the 1990s and the 'Roadmap for Discipline-flourishing Democracy' that was announced in 2003.

Following the 1988 pro-democracy uprising and the collapse of the BSPP regime, the new SLORC regime opened up for general election in 1990. The election returned a landslide victory for the pro-democracy and ethnic opposition, thereby alerting the military to the dangers of premature liberalization. The military annulled the election results and argued that parliamentary politics could only be re-introduced after a new constitution was in place. The claim was made that the election had only been for a National Convention, which was initiated in 1993 as a military-dominated, noninclusive and ineffectual process (Steinberg, 2013). It can thus be argued that the experiences with the National Convention set the stage for the process of designing the 2008 Constitution, but also that they reinforced the tatmadaw's insistence on statebuilding as a prerequisite for political liberalization (Egreteau, 2016).

In agreement with this approach, the 1990s was marked by military build-up and offensives combined with bilateral ceasefire agreements that strengthened the praetorian state, meaning that the military rulers could later initiate a controlled democratic opening from a position of strength (Egreteau, 2016; Sadan, 2016). SPDC unveiled its Roadmap for Discipline-flourishing Democracy in 2003 and designed the 2008 constitution, which structures representation, parliamentary politics, government, decentralization and public administration in ways that reflect military's position on state security and political stability (Williams, 2014).

The imposed transition discourse thus argues that the USDP-government's reforms should not be understood as a pacted transition, but rather as a process of rolling out the military's constitutional framework and co-opting the pro-democracy and profederalism opposition (Egreteau, 2016). The USDP-government did not hold substantive negotiations with the pro-democracy opposition but sought to domesticate key political actors and parties into electoral democracy and parliamentary politics. Likewise, the government sought to pacify ethnic armed 
organizations through ceasefire agreements and development concessions without political peace negotiations and settlements (Lee, 2016). The imposed transition discourse thus holds that there is little evidence of the kind of negotiations and pacts that are emphasized within the transition approach in democratization studies.

The imposed transition discourse sees Myanmar's reform as an autocratic, controlled and sequenced opening, where the purpose has been to design a relatively stable hybrid regime with the Military in a guardian role (Bünte, 2014). Against this background, the landslide victory of NLD at the 2015 election came as a surprise to the government, political commentators and academic scholars. The election results and the change of government that followed is not, however, taken to mean that Myanmar has undergone a transition to democracy. On the contrary, the imposed transition discourse argues that the military has constructed constitutional, institutional and political structures that give them substantive political control even with a democratically elected pro-democracy government (Selth, 2018).

\section{The outcomes of Myanmar's imposed transition}

The period since 2011 has been marked by a polarized debate about Myanmar's mode of transition, but also a shift in the relative importance of the two discourses. While the pacted transition discourse held a dominant position during the USDPgovernment period, the imposed transition discourse has gained more influence in recent years. The most plausible explanation for this discursive shift seems to be that the military's non-democratic roles and strategies have been rendered more visible in the context of a democratically elected NLD-government, most dramatically demonstrated by the ethnic cleansing of Rohingyas in Rakhine State in 2017. We will hence argue that there is a convergence in the understanding of the democratic opening as being designed and imposed by the tatmadaw. When it comes to the dialog initiatives during the USDP-government, a divide continues to exist between those who see this as an attempt to negotiate and institutionalize new rules and those who see it as a mere roll-out of the 2008 Constitution. Regardless of what the intentions may have been, most scholars acknowledge that there are few examples of substantive institutional changes that have come about through negotiations and pacts.

If Myanmar has undergone a military-imposed democratic opening, what kind of outcomes have followed? Although it is not given that it is a transition to democracy, the natural starting point for assessing the outcome is nevertheless the core principles and institutional means of democracy (Beetham, 1999, 2004). The field of democracy assessments are marked by a general divide between studies based on 
procedural definitions of democracy that emphasize core democratic institutions, and assessments that employ a substantive definition of democracy (Törnquist, 2013).

Within the first tradition, Møller and Skaaning (2013), for example, provide a taxonomic hierarchy of political regimes where Myanmar would meet their criteria for being classified as a minimalist or electoral democracy. This classification of Myanmar as a formal democracy says less about its democratic substance.

Coming from the alternative tradition of defining democracy in substantive terms, Beetham calls for attention to the core principles of democracy, defined as 'control by citizens over their collective affairs and equality between citizens in the exercise of that control' (Beetham, 1999, p. 91, italics in original). These core democratic principles may be operationalized in different ways for the purpose of concrete democracy assessments (Beetham, 2004). IDEA (2017), for example, emphasizes five main dimensions of democracy: representative government; fundamental rights; checks on government; impartial administration; and, participatory engagement. Adding to this, Törnquist (2013) draws attention to how public affairs and demos are defined, and the capacity of people to exert substantive political control.

It is beyond the scope of this article to undertake a comprehensive democracy assessment. Given the space constraints, we will instead use Beetham's core principles as heuristic guidelines for a brief examination of the outcome of the democratic opening. We will especially highlight three key elements of popular political control in contemporary Myanmar: the definition of public affairs; the role of elected parliaments in policy-making, and; the channels of popular representation and participation. Another key issue in the assessment of democratic substance - the definition and substance of citizenship - is left out due to space constraints (South and Lall, 2018).

\section{Vital public affairs exempted from democratic control}

A key feature of Myanmar's current political system is that important public affairs do not come under democratic decision-making. This is especially the case for matters of state security, where the tatmadaw has sovereign authority. Myanmar's 2008 constitution contains several provisions that safeguard the autonomy and authority of the military (Bünte, 2014, 2017; Egreteau, 2016; Huang, 2013; Taylor, 2014; Williams, 2014). The constitution creates the National Defence and Security Council (NDSC) as a powerful non-elected body that is under military control. Furthermore, the tatmadaw has the right to independently administer all affairs of the armed forces; the President of the Union lacks the power of Commander-in-Chief; and, the chief commander is the highest arbiter of military justice and can take full control of the state (the legislature, executive and judiciary) during times of emergency (Union of Myanmar, 2008). These provisions, which were designed by the military and justified with 
reference to the need for sovereignty, unity and stability, mean that the armed forces have extensive control over vital public affairs, especially when state security is deemed to be under threat.

As a political extension of this sovereign authority on security issues comes the tatmadaw's positions of power within government and public administration (Bünte, 2017; Egreteau, 2017; Maung Aung Myoe, 2017). The constitution specifies that the Ministers and Deputy Ministers for Defence; Home Affairs; and, Border Affairs are to be nominated by the Commander-in-Chief. This also grants the military a key role in public administration, although the powerful General Administration Department (GAD) has recently been transferred from the military to the civilian domain of authority. Whereas the modality of military influence has changed, from ruler to guardian, the tatmadaw continues to hold multiple and important positions of power under the 2008 Constitution (Bünte, 2014; Egreteau, 2014). Transforming civilmilitary relations is thus a foremost concern for democratic deepening in Myanmar (Maung Aung Myoe, 2017).

It is also notable that key questions of economic and social development do not come under democratic political control. Starting in the 1990s, Myanmar underwent a partial economic liberalization that shifted economic control from the state to military-owned and crony companies, where the military-owned Union of Myanmar Economic Holdings (UMEH) and Myanmar Economic Corporation (MEC) became especially powerful and omnipresent conglomerates (Ford et al., 2015; Jones, 2013). Economic liberalization was furthered during the USDP government period, including a large increase in foreign direct investment (Bello, 2018). In conflict-affected areas, important economic activities are under the control of armed non-state actors (ethnic armed organizations, militias, border guard forces), partly as a result of clientelist relations with the military and ceasefire agreements with the USDP government (Woods, 2011). Various hybrid governance arrangements have been created and raise critical questions about political control and legitimacy (South et al., 2018). Such state-economy relations mean that key aspects of development are withheld from democratic control.

This lack of political control over security and development affairs is especially acute and contentious in ethnic states, many of which have been marked by protracted armed conflicts and resource grabbing. Myanmar has since independence seen multiple conflicts between the tatmadaw's agenda of building a unitary and centralized state under military guardianship, and ethnic nationalities demanding equality, representation and self-determination within a federal state (Burke et al., 2017; Smith, 1991, 2007). 
The general problem of limited local control over local public affairs is especially acute in natural resource governance as many ethnic states are resource rich but remain under centralized and de facto military administration. Power-sharing thus concerns both how to manage natural resources and revenues effectively (good governance), and how to share responsibilities and revenues between the various levels of governments (Kramer, 2010). The constitution grants state and region governments some authority to legislate on resource extraction and collect taxes, but this is limited to less valuable resources. While some argue that the constitution contains the building blocks of federalism, ethnic organizations maintain that it is only superficially federal-like (Holliday, Maw Htun Aung, \& Joelene, 2015). Transforming central-local relations is thus a key concern for substantive democratization and conflict resolution in Myanmar (Kramer, 2015; Thet Aung Lynn \& Mari Oye, 2014).

In conclusion, it can be observed that the sovereign powers of the military, the limited political authority over economic development, and the centralized unitary state structure mean that vital public affairs are exempted from democratic control. This limits the substance of democracy, even amidst institutionalized electoral democracy.

\section{Constrained parliamentary politics and top-down policy-making}

Myanmar's military-designed 2008 Constitution provides an institutional framework for electoral democracy and parliamentary politics (Kean, 2014; Lidauer, 2014). It established the Pyidaungsu Hluttaw (Union Parliament) as a bicameral legislature consisting of a House of Representatives (Pyithu Hluttaw) and a House of Nationalities (Amyotha Hluttaw). The Union Parliament is the basis for the election of the President, who in turn appoints government ministers and deputy ministers (Union of Myanmar, 2008).

The 2008 Constitution also creates state/region parliaments and governments (Nixon et al. 2015). These sub-national parliaments are, however, not the basis for state/division governments, which are instead headed by Chief Ministers appointed by the President. The Chief Minister nominates cabinet ministers in consultation with the President, and local state/region ministers that function as coordinators and advisors to local offices of union ministries (Lidauer, 2014). Six self-administered areas have 'leading bodies' headed by an appointed chair. At the local level, there are also townships and districts led by senior officials of the General Administration Department (GAD) (Kyi Pyar Chit Saw \& Arnold, 2014).

This constitutional framework means that it is only at the Union level that there is a democratic link from the elected assembly to the executive. Local parliaments have little power in regards to the chief minister and the state/region government. But even the power of the union parliament is constrained, as policy-making is largely 
outside the ambit of parliamentary politics.

Policy-making in Myanmar is typically centralized and top-down, reflecting a long legacy of military decision-making structures. Before 2011, policy processes in Myanmar were under the direct command of a small group of senior generals. State ministries had little involvement in policy-making and there was virtually no input from the public. Several ethnic states were, in whole or part, controlled and administered by the military or ethnic armed organizations. The USDP government introduced parliamentary processes, but policy-making remained top-down, dominated by the President and a limited number of trusted ministers and advisors, some from government-affiliated civil society organizations (Egreteau, 2016).

The civil service played a limited role in developing and reviewing policies. Ministries implemented instructions, but had little devolved authority. Decades of top-down governance produced a hierarchical and passive organizational culture within the bureaucracy that also continued after the shift from military rule. This means that parliamentary checks on government were weak, while rule of law as an alternative channel of accountability was largely absent under military rule and remains weak also after the democratic opening (Cheesman, 2015; Kyaw Min San, 2012; PrasseFreeman, 2015).

The shift to a democratically elected and pro-democracy NLD-government created new possibilities for more transparent and inclusive policymaking, but this is hampered by an organizational culture of hierarchical decision-making that permeates the NLD, the government and the civil service. There is little devolution of decision-making authority within the party, the government, the state ministries and the civil service. Military-NLD relations also remain contentious in parliament, government and the peace process (Maung Aung Myoe, 2018; Walton, 2018).

In conclusion, it can be observed that democratic parliamentary politics is structurally constrained, as the elected assemblies have relatively little influence on policy-making and limited power to function as a check on government. This means that although the democratic opening has reintroduced parliamentary politics, challenges remain in terms of parliamentary control of public affairs.

\section{Unequal and weak political representation}

Myanmar's democratic opening has re-introduced electoral democracy and the constitution provides an institutional framework for political representation, but the substance of representation has proven to be unequal and weak. Myanmar has had two general elections based on the 2008 Constitution. While the 2010 election was found to be deeply flawed, the 2015 election was conducted as a free multi-party 
election. It was, however, not fully fair due to $25 \%$ of parliamentary seats being reserved for the military; disenfranchisement of a large number of permanent residents without formal citizenship (especially Rohingyas); and a first-past-the-post electoral system that impedes proportional representation of Myanmar's multi-ethnic electorate (Lemargie, Reynolds, Erben, \& Ennis, 2014). More fundamentally, the definition of demos also rests on Myanmar's contentious constructions of citizenship, which raise critical questions about the extent of political equality (South \& Lall, 2018). Although Myanmar now has elected union and state/region parliaments, their composition tends to be skewed in favour of the military over civilians; the ethnic and religious majority over minorities; and, men over women (Egreteau, 2016).

Beyond such problems of skewed descriptive representation, Myanmar is marked by problems of substantive representation. This holds true both for mediated representation through political parties and direct participation of civil society organizations (CSOs). The re-introduction of electoral democracy has been followed by a proliferation of political parties, but most of them have not won any seats and almost all have limited capacity to function as effective channels of popular representation (Stokke et al., 2017).

Poor party institutionalization reflects the troubled history of party development. In simplified terms, the diversity of parties can be grouped into three main clusters: parties that originate from the military; parties that are rooted in the pro-democracy movement since the 1980s; and, ethnic minority parties (Stokke et al., 2015). All three clusters, and especially the large number of ethnic parties, contain a divide between old movement parties that contested the 1990 election and new electoralist parties that were established for the purpose of contesting the 2010 election. Both the old movement parties and the new electoralist parties are poorly institutionalized, as the former were disbanded and persecuted during military rule and the latter are leadership-centric and weak organizations created for the purpose of contesting elections. The main exceptions are the two dominant parties - USDP and NLD - which have union-wide organizational structures, but also major shortcomings in terms of weak party platforms and limited internal democracy. Common problems of party building mean that parties in Myanmar have limited capacity to ensure popular representation (Blaževič, 2016; Egreteau, 2017; Stokke et al., 2015). Few, if any, have developed strong relations with local communities, most parties are centralized organizations that grant excessive power to the leadership, and building effective alliances with other parties and CSOs have proven to be difficult.

If popular representation through political parties is hampered by weak party institutionalization, does civil society provide viable alternatives? Civil society organizations in Myanmar have for long had complex and contentious relations with 
the state. The period of military rule was characterized by state suppression of oppositional political movements, but also the emergence of regime-initiated mass organizations (Burma Center Netherlands \& Transnational Institute, 1999; Kyaw Yin Hlaing, 2007). The democratic opening has brought a rapid growth in civil society organizations, and has also expanded the space for political advocacy (Wells \& Kyaw Thu Aung, 2014). This opening is reflected in the increased numbers and activities of CSOs that seek to engage with local public administration or influence policy-making at the union level. While there are some cases where the government has invited inputs from civil society into policy-making processes, especially during the USDPgovernment, there are relatively few examples of substantive civil society influence on policy (Kim Jolliffe \& Mears, 2016). The more common experience is that CSOs have limited political access and influence. Such constraints combined with the fragmented character of civil society, mean that although CSOs play important roles in society they do not provide viable alternative channels for popular political representation.

In conclusion, it can be argued that Myanmar has seen the re-introduction of electoral democracy, but actual popular representation and participation are hampered by limited political capacity of parties and problems of political access among CSOs. While this situation calls for transformative alliances and agendas that can push for more substantive democracy, there have been few examples of such initiatives.

\section{Conclusion}

This article has addressed the questions of the mode and outcome of Myanmar's transition from military rule. While the early reform period was dominated by a discourse that portrayed Myanmar as a pacted transition, the dominant position in recent years has been that Myanmar should be understood as a military-imposed transition. This mode of transition has produced a formal institutional framework for electoral democracy and parliamentary politics. It does not mean, however, that there is effective popular control of public affairs based on political equality. On the contrary, the democratic chain from citizens, through mediated representation or direct participation, into democratic decision-making and policy implementation are hampered at all levels of the chain: Vital public affairs are exempted from democratic control; parliamentary politics is constrained and policy-making remain centralized and top-down; and, popular political representation and participation are unequal and weak

These observations support the general conclusion that Myanmar's imposed 
transition has institutionalized a hybrid form of rule where there are new and important democratic spaces, but where the substance of democracy is curtailed by constitutional regulations that secure military positions of power and limit popular democratic control of public affairs. Nevertheless, Myanmar's political trajectory is to some extent open-ended, as demonstrated by the 2015 election and the subsequent change of government. A critical question that follows from our review, but goes beyond the scope of this article, is thus about the prospects and sources of more substantial democratization. For the time being, with few signs of effective forces of transformative democratic politics, Myanmar seems most likely to remain in a relatively stable state of hybrid rule amidst institutionalized electoral democracy, parliamentary politics and decentralization.

\section{References}

Ardeth Maung Thawnghmung. (2016). The Myanmar Elections 2015: Why the National League for Democracy Won a Landslide Victory. Critical Asian Studies, 48(1), 132-142.

Ardeth Maung Thawnghmung, \& Maung Aung Myoe. (2007). Myanmar in 2006: Another Year of Housekeeping. Asian Survey, 47(1), 194-199.

Ardeth Maung Thawnghmung, \& Maung Aung Myoe. (2008). Myanmar in 2007: A Turning Point on the "Roadmap"? Asian Survey, 48(1), 13-19.

Beetham, D. (1999). Democracy and Human Rights. Oxford: Polity Press.

Beetham, D. (2004). Towards a universal framework for democracy assessment. Democratization, 11(2), 1-17.

Bello, W. (2018). Paradigm Trap: The development establisment's embrace of Myanmar and how to break loose. Amsterdam: Transnational Institute.

Blaževič, I. (2016). The Challenges Ahead. Journal of Democracy, 27(2), 101-115.

Bünte, M. (2014). Burma's Transition to Quasi-Military Rule: From Rulers to Guardians? Armed Forces \& Society, 40(4), 742-764.

Bünte, M. (2016). Myanmar's Protracted Transition: Arenas, Actors, and Outcomes. Asian Survey, 56(2), 369-391.

Bünte, M. (2017). The NLD-Military Coalition in Myanmar: Military Guardianship and Its Economic Foundations. In P. W. Chambers \& N. Waitoolkiat (Eds.), Khaki Capital: The Political Economy of the Military in Southeast Asia. Copenhagen: NIAS Press.

Burke, A., Williams, N., Barron, P., Jolliffe, K., \& Carr, T. (2017). The Contested Areas of Myanmar: Subnational Conflict, Aid, and Development. Yangon: Asia Foundation.

Burma Center Netherlands, \& Transnational Institute (Eds.). (1999). Strengthening Civil Society in Burma: Possibilities and Dilemmas for International NGOs. Chiang Mai: Silkworm.

Burma News International. (2017). Deciphering Myanmar's Peace Process: A Reference Guide 2016. Chiang Mai: Burma News International. 
Callahan, M. P. (2003). Making Enemies: War and State Building in Burma. Ithaca: Cornell University Press.

Camroux, D., \& Egreteau, R. (2010). Normative Europe meets the Burmese Garrison State: Processes, Policies, Blockages and Future Possibilities. In N. Cheesman, M. Skidmore, \& T. Wilson (Eds.), Ruling Myanmar: From Cyclone Nargis to National Elections. Singapore: ISEAS.

Cheesman, N. (2015). Opposing the Rule of Law: How Myanmar's Courts Make Law and Order. Cambridge: Cambridge University Press.

Cheesman, N., Farrelly, N., \& Wilson, T. (Eds.). (2014). Debating Democratization in Myanmar. Singapore: ISEAS.

Cheesman, N., Skidmore, M., \& Wilson, T. (Eds.). (2010). Ruling Myanmar: From Cyclone Nargis to National Elections. Singapore: ISEAS.

Cheesman, N., Skidmore, M., \& Wilson, T. (Eds.). (2012). Myanmar's Transition: Openings, Obstacles and Opportunities. Singapore: ISEAS.

Chow, J. T., \& Easley, L.-E. (2016). Persuading Pariahs: Myanmar's Strategic Decision to Pursue Reform and Opening. Pacific Affairs, 89(3), 521-542.

Croissant, A., \& Kamerling, J. (2013). Why Do Military Regimes Institutionalize? Constitution-making and Elections as Political Survival Strategy in Myanmar. Asian Journal of Political Science, 21(2), 105-125.

Egreteau, R. (2014). The Continuing Political Salience of Military in Post-SPDC Myanmar. In N. Cheesman, N. Farrelly, \& T. Wilson (Eds.), Debating Democratization in Myanmar. Singapore: ISEAS.

Egreteau, R. (2016). Caretaking Democratization: The Military and Political Change in Myanmar. London: Hurst.

Egreteau, R. (2017). Parliamentary Development in Myanmar: An Overview of the Union Parliament 2011-2016. Yangon: Asia Foundation.

Egreteau, R., \& Jagan, L. (2013). Soldiers and Diplomacy in Burma: Understanding the Foreign Relations of the Burmese Praetorian State. Singapore: NUS Press.

Eisenstadt, T. (2000). Eddies in the third wave: Protracted transitions and theories of democratization. Democratization, 7(3), 3-24.

Ford, M., Gillan, M., \& Thein, H. H. (2015). From Cronyism to Oligarchy? Privatisation and Business Elites in Myanmar. Journal of Contemporary Asia, 46(1), 18-41.

Gravers, M., \& Ytzen, F. (Eds.). (2014). Burma/Myanmar: Where Now? Copenhagen: NIAS Press.

Grugel, J., \& Bishop, M. L. (2014). Democratization: A Critical Introduction. New York: Palgrave-Macmillan.

Holliday, I. (2011). Burma Redux: Global Justice and the Quest for Political Reform in Myanmar. Hong Kong: Hong Kong University Press.

Holliday, I., Maw Htun Aung, \& Joelene, C. (2015). Institution Building in Myanmar: The Establishment of Regional and State Assemblies. Asian Survey, 55(4), 641664.

Huang, R. L. (2013). Re-thinking Myanmar's political regime: military rule in Myanmar and implications for current reforms. Contemporary Politics, 19(3), 247-261.

Huang, R. L. (2016). Myanmar's way to democracy and the limits of the 2015 elections. Asian Journal of Political Science, 25(1), 25-44.

IDEA. (2017). The Global State of Democracy 2017: Exploring Democracy's Resilience. Stockholm: Institute for Democracy and Electoral Assistance. 
James, H. (2006). Myanmar in 2005: In a Holding Pattern. Asian Survey, 46(1), 162167.

Jones, L. (2013). The Political Economy of Myanmar's Transition. Journal of Contemporary Asia, 44(1), 144-170.

Jones, L. (2014). Explaining Myanmar's regime transition: the periphery is central. Democratization, 21(5), 780-802.

Kean, T. (2014). Myanmar's Parliament: From Scorn to Significance. In N. Cheesman, N. Farrelly, \& T. Wilson (Eds.), Debating Democratization in Myanmar. Singapore: ISEAS.

Kim Jolliffe, \& Mears, E. S. (2016). Strength in Diversity: Towards Universal Education in Myanmar's Ethnic Areas. Yangon: Asia Foundation.

Kipgen, N. (2016). Democratisation of Myanmar. Oxon: Routledge.

Kramer, T. (2010). Ethnic Conflict in Burma: The Challenge of Unity in a Divided Country. In L. Dittmer (Ed.), Burma or Myanmar? The Struggle for National Identity. Singapore: World Scientific.

Kramer, T. (2015). Ethnic Conflict and Lands Rights in Myanmar. Social Research, 82(2), 355-374.

Kyaw Min San. (2012). Critical Issues for the Rule of Law in Myanmar. In N. Cheesman, M. Skidmore, \& T. Wilson (Eds.), Myanmar's Transition: Openings, Obstacles and Opportunities. Singapore: ISEAS.

Kyaw Yin Hlaing. (2004). Myanmar in 2003: Frustration and Despair? Asian Survey, 44(1), 87-92.

Kyaw Yin Hlaing. (2007). Associational Life in Myanmar: Past and Present. In N. Ganesan \& Kyaw Yin Hlaing (Eds.), Myanmar: State, Society and Ethnicity. Singapore: ISEAS.

Kyaw Yin Hlaing. (2014a). Reassessing the economic sanctions imposed by Western governments on Myanmar. In Kyaw Yin Hlaing (Ed.), Prisms on the Golden Pagoda: Perspectives on the Politics of National Reconciliation in Myanmar. Singapore: Singapore University Press.

Kyaw Yin Hlaing. (2014b). The unexpected arrival of a new political era in Myanmar. In Kyaw Yin Hlaing (Ed.), Prisms on the Golden Pagoda: Perspectives on the Politics of National Reconciliation in Myanmar. Singapore: Singapore University Press.

Kyi Pyar Chit Saw, \& Arnold, M. (2014). Administering the State in Myanmar: An Overview of the General Administration Department. Yangon: The Asia Foundation.

Lall, M. (2016). Understanding Reform in Myanmar: People and Society in the Wake of Military Rule. London: Hurst.

Lee, J. (2016). Settlements in the Civil Wars of Myanmar and Sri Lanka: The Success, Failure and Deception of the Peace Process. Millennial Asia, 7(1), 63-76.

Lemargie, K., Reynolds, A., Erben, P., \& Ennis, D. (2014). Electoral System Choice in Myanmar's Democratization Debate. In N. Cheesman, N. Farrelly, \& T. Wilson (Eds.), Debating Democratization in Myanmar. Singapore: ISEAS.

Lidauer, M. (2014). Towards a new state in Myanmar. In M. Gravers \& F. Ytsen (Eds.), Burma/Myanmar: Where Now? Copenhagen: NIAS Press.

Lintner, B. (2014). The Kyi to the Great Game East. In M. Gravers \& F. Ytsen (Eds.), Burma/Myanmar: Where Now? Copenhagen: NIAS Press. 
Linz, J. J., \& Stepan, A. (1996). Problems of Democratic Transition and Consolidation: Southern Europe, South America, and Post-Communist Europe. Baltimore: The Johns Hopkins University Press.

Mahoney, J., \& Snyder, R. (1999). Rethinking Agency and Structure in the Study of Regime Change. Studies in Comparative International Development, Summer 1999, 3-32.

Maung Aung Myoe. (2009). Building the Tatmadaw: Myanmar Armed Forces Since 1948. Singapore: ISEAS.

Maung Aung Myoe. (2014). The soldier and the state: the Tatmadaw and political liberalization in Myanmar since 2011. South East Asia Research, 22(2), 233249.

Maung Aung Myoe. (2015). Myanmar's China Policy since 2011: Determinants and Directions. Journal of Current Southeast Asian Affairs, 34(2), 21-54.

Maung Aung Myoe. (2017). Emerging patterns of civil-military relations. Southeast Asian Affairs, 259-273.

Maung Aung Myoe. (2018). Partnership in Politics: The Tatmadaw and the NLD in Myanmar since 2016. In J. Chambers, G. McCarthy, N. Farrelly, \& Chit Win (Eds.), Myanmar Transformed? People, Places and Politics. Singapore: ISEAS.

Mullen, M. (2016). Pathways that Changed Myanmar. London: Zed.

Munck, G. L., \& Leff, C. S. (1997). Modes of Transition and Democratization: South America and Eastern Europe in Comparative Perspective. Comparative Politics, 29(3), 343-362.

Nakanishi, Y. (2013). Strong Soldiers, Failed Revolution: The State and Military in Burma, 1962-88. Singapore: NUS Press.

O'Donnell, G., \& Schmitter, P. C. (1986). Transitions from Authoritarian Rule: Tentative Conclusions about Uncertain Democracies. Baltimore: Johns Hopkins University Press.

Pedersen, M. B. (2012). Rethinking International Assistance to Myanmar in a Time of Transition. In N. Cheesman, M. Skidmore, \& T. Wilson (Eds.), Myanmar's Transition: Openings, Obstacles and Opportunities. Singapore: ISEAS.

Pedersen, M. B. (2014). Myanmar's Democratic Opening: The Process and Prospect of Reform. In N. Cheesman, N. Farrelly, \& T. Wilson (Eds.), Debating Democratization in Myanmar. Singapore: ISEAS.

Prasse-Freeman, E. (2015). Conceptions of Justice and the Rule of Law. In D. I. Steinberg (Ed.), Myanmar: The Dynamics of an Evolving Polity. Boulder: Lynne Rienner.

Sadan, M. (Ed.) (2016). War and Peace in the Borderlands of Myanmar: The Kachin Ceasefire, 1994-2011. Copenhagen: NIAS Press.

Schmitter, P. C. (2017). The Role of Elites in Democratization. Journal of Chinese Political Science, 23(1), 33-46.

Schmitter, P. C., \& Karl, T. L. (1991). Modes of transition in Latin America, Southern and Eastern Europe. International Social Science Journal, 128(269-284).

Selth, A. (2001). Burma's Armed Forces: Power without Glory. Norwalk: EastBridge.

Smith, M. (1991). Burma: Insurgency and the Politics of Ethnicity. London: Zed.

Smith, M. (2007). State of Strife: Ethnic Conflict in Burma. Honolulu: East-West Center. 
Smith, M. (2018). Ethnic Politics and Citizenship in History. In A. South \& M. Lall (Eds.), Citizenship in Myanmar: Ways of Being in and from Burma. Singapore: ISEAS.

South, A., \& Lall, M. (Eds.). (2018). Citizenship in Myanmar: Ways of Being in and from Burma. Singapore: ISEAS.

South, A., Schroeder, T., Jolliffe, K., Mi Kun Chan Non, Sa Shine, Kempel, S., . . . Naw Wah Shee Mu. (2018). Between Ceasefires and Federalism: Exploring Interim Arrangements in the Myanmar Peace Process. Yangon: Covenant Consult.

Steinberg, D. I. (2013). Burma/Myanmar: What Everyone Needs to Know (2 ed.). Oxford: Oxford University Press.

Steinberg, D. I. (Ed.) (2015). Myanmar: The Dynamics of an Evolving Polity. Boulder: Lynne Rienner.

Stokke, K., Khine Win, \& Soe Myint Aung. (2015). Political Parties and Popular Representation in Myanmar's Democratisation Process. Journal of Current Southeast Asian Affairs, 34(3), 3-35.

Stokke, K., Vakulchuk, R., \& Øverland, I. (2017). Myanmar: A Political Economy Analysis. Oslo: Norwegian Institute of International Affairs.

Stradiotto, G. A., \& Guo, S. (2010). Transitional Modes of Democratization and Democratic Outcomes. International Journal on World Peace, 27(4), 5-40.

Taylor, R. H. (2014). The third constitution of the Union of Myanmar. In Kyaw Yin Hlaing (Ed.), Prisms on the Golden Pagoda: Perspectives on the Politics of National Reconciliation in Myanmar. Singapore: Singapore University Press.

Thet Aung Lynn, \& Mari Oye. (2014). Natural Resources and Subnational Governments in Myanmar. Yangon: Asia Foundation.

Tin Maung Maung Than. (2001). Myanmar (Burma) in 2000. Asian Survey, 41(1), 148155.

Törnquist, O. (2013). Assessing Dynamics of Democratization: Transformative Politics, New Institutions, and the Case of Indonesia. New York: Palgrave Macmillan.

Turnell, S. (2012). Reform and Its Limits in Myanmar's Fiscal State. In N. Cheesman, M. Skidmore, \& T. Wilson (Eds.), Myanmar's Transition: Openings, Obstacles and Opportunities. Singapore: ISEAS.

Union of Myanmar. (2008). Constitution of the Republic of the Union of Myanmar. Nay Pyi Taw: Union of Myanmar.

Walton, M. (2018). Reflections on Myanmar Under the NLD so far. In J. Chambers, G. McCarthy, N. Farrelly, \& Chit Win (Eds.), Myanmar Transformed? People, Places and Politics. Singapore: ISEAS.

Ware, A., \& Laoutides, C. (2018). Myanmar's 'Rohingya' Conflict. London: C. Hurst.

Wells, T., \& Kyaw Thu Aung. (2014). Village Networks, Land Law, and Myanmar's Democratization. In N. Cheesman, N. Farrelly, \& T. Wilson (Eds.), Debating Democratization in Myanmar. Singapore: ISEAS.

Williams, D. C. (2014). What's so bad about Burma's 2008 Constitution? A guide for the perplexed. In M. Crouch \& T. Lindsey (Eds.), Law, Society and Transition in Myanmar. Oxford: Hart.

Win Min. (2010). Looking Inside the Burmese Military. In L. Dittmer (Ed.), Burma or Myanmar? The Struggle for National Identity. Singapore: World Scientific.

Woods, K. (2011). Ceasefire capitalism: military-private partnerships, resource concessions and military-state building in the Burma-China borderlands. Journal of Peasant Studies, 38(4), 747-770. 


\begin{tabular}{|c|c|c|c|c|c|}
\hline & & \multicolumn{2}{|c|}{ Authoritarian regime } & \multicolumn{2}{|c|}{ Pro-democracy/pro-federalism opposition } \\
\hline & & Hardliners & Softliners & Softliners & Hardliners \\
\hline 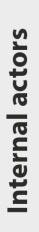 & $\begin{array}{l}\begin{array}{l}\text { Union-wide } \\
\text { or Bamar } \\
\text { actors }\end{array} \\
\text { Ethnic } \\
\text { minority } \\
\text { actors }\end{array}$ & $\begin{array}{l}\text { Reform-averse } \\
\text { military actors }\end{array}$ & $\begin{array}{l}\text { Reform-oriented } \\
\text { military actors }\end{array}$ & $\begin{array}{l}\text { Engagement-oriented } \\
\text { Union-wide or Bamar } \\
\text { political parties and NGOs } \\
\text { Engagement-oriented } \\
\text { ethnic armed organisations, } \\
\text { political parties and NGOs }\end{array}$ & $\begin{array}{c}\text { Engagement-averse } \\
\text { Union-wide or Bamar } \\
\text { political parties and CSOs } \\
\text { Engagement-averse } \\
\text { ethnic armed organisations, } \\
\text { political parties and CSOs }\end{array}$ \\
\hline \multirow{2}{*}{ 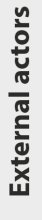 } & $\begin{array}{l}\text { Burman } \\
\text { diaspora } \\
\text { actors }\end{array}$ & \multirow{2}{*}{\multicolumn{2}{|c|}{$\begin{array}{l}\text { International actors in pragmatic } \\
\text { partnership with the military regime }\end{array}$}} & $\begin{array}{l}\text { Engagement-oriented } \\
\text { diaspora actors }\end{array}$ & $\begin{array}{l}\text { Engagement-averse } \\
\text { diaspora actors }\end{array}$ \\
\hline & $\begin{array}{l}\text { International } \\
\text { actors }\end{array}$ & & & $\begin{array}{c}\text { Engagement-oriented } \\
\text { international } \\
\text { actors }\end{array}$ & $\begin{array}{c}\text { Engagement-averse } \\
\text { international } \\
\text { actors }\end{array}$ \\
\hline
\end{tabular}

Figure 1. Myanmar's democratic opening understood as a pacted transition. 